Список использованных источников:

1. Артоболевская А.Д. Первая встреча с музыкой. URL : https://notkinastya.ru/artobolevskaya-a-pdf/ (дата обращения 04.11.2020).

2. Баренбойм Л.А. Пусть к музыцированию. Ленинград : Сов. композитор, 1976.

3. Григорьев Л., Платек Я. Современные пианисты: Биографические очерки. Москва : Сов. Композитор, 1985

4. Леймер К., Гизекинг В. Обучение игре на фортепиано по Леймеру - Гизекингу. Москва : Классика - XXI, 2009. $116 \mathrm{c}$.

5. Мартинсен К.А. Индивидуальная фортепианная техника. Москва : Музыка, 1996. 220 с.

6. Нейгауз Г.Г. Об искусстве фортепианной игры. Записки педагога. Москва : Музыка, 1958. 207 с.

7. Сапсович А. Профессиональная память музыканта-исполнителя в контексте специальных музыкальных способностей / Музичне мистецтво і культура. Науковий вісник ОНМА ім. А.В. Нежданової ; гол. ред. К. Фламм. Одеса : Астропринт, 2019. Вип. 29/1. С. 179-191.

8. Цветаева М. Мать и музыка. URL : http://tsvetaeva.lit-info.ru/tsvetaeva/proza/mat-i-muzyka.htm (дата обращения: 05.11.2020).

\title{
References:
}

1. Artobolevskaya A.D. (1992). Pervaya vstrecha s musikoj [First meeting with music]. https://notkinastya.ru/ artobolevskaya-a-pdf/ [in Russian]

2. Barenboim L.A. (1976). Put' v muzicirovanie [The way to music]. Sov. composer [in Russian]

3. Grigoriev L., Platek J. (1985). Sovremennie pianisti. Biograficheskie ocherki [Modern pianists: Biographical sketches]. Sov. Composer [in Russian]

4. Leimer K., Gieseking V. (2009). Obuchenie igre na fortepiano po shkole Leimera - Gisekinga [Learning to play the piano according to Leimer - Gieseking]. Classic - XXI. 116 p. [in Russian]

5. Martinsen K.A. (1996). Individual'naya fortepiannaya tehnika [Individual piano technique]. Music, 220 p. [in Russian]

6. Neuhaus G.G. (1958). Iskusstvo fortepiannoj igri [The art of piano playing. Teacher's notes]. Music, 207 p. [in Russian]

7. Sapsovich O. (2019). Professional'naya pamyat' muzykanta-ispolnitelya v kontekste spetsial'nykh muzykal'nykh sposobnostey [Professional memory of a musician-performer in the context of special musical abilities] / Musical art and culture. Science newsletter of the ONMA named after A.V. Nezhdanovo; Main. ed. K. Flamm. Astroprint. Band. 29/1. pp. 179-191 [in Russian]

8. Tsvetaeva M. Mat' i musica [Mother and Music]. http://tsvetaeva.lit-info.ru/tsvetaeva/proza/mat-i-muzyka.htm [in Russian]

\section{DOI https://doi.org/10.51647/kelm.2020.5.4.11}

\section{CECHY UKRAIŃSKIEJ FOTOKSIĄŻKI JAKO OBIEKTU ART DESIGN}

\author{
Anna Safronova \\ aspirant Katedry Ergonomii i Projektowania \\ Kijowskiego Narodowego Uniwersytetu Technologii i Projektowania (Kijów, Ukraina) \\ ORCID ID: 0000-0003-4215-2646 \\ elrossa@ukr.net \\ Olena Safronova \\ kandydat nauk technicznych, docent, \\ kierownik Katedry Projektowania Wnętrz i Mebli \\ Kijowskiego Narodowego Uniwersytetu Technologii i Projektowania (Kijów, Ukraina) \\ ORCID ID: 0000-0002-3887-4825
}

\begin{abstract}
Adnotacja. Praca traktuje fotoksiążkę jako formę prezentacji sztuki, której celem jest komunikacja autora z widzem poprzez zawarte w niej zdjęcia, ich symboliczną treść, kompozycję i porządek. Na podstawie analizy źródeł naukowych, analizy strukturalno-morfologicznej i merytorycznej współczesnych zagranicznych i ukraińskich fotoksiążek opracowano klasyfikację ich typów zgodnie z metodą prezentacji treści; zidentyfikowano najczęstsze podstawy łączenia zdjęć w serię: wspólny temat; ogólna idea; ogólna fabuła; wspólność formalnych znaków, skojarzeń. Podkreślono, że autorstwo najbardziej udanych ukraińskich książek fotograficznych, które zyskały uznanie na Międzynarodowych i wszechrosyjskich wystawach i konkursach, należy do artystów Charkowskiej Szkoły Fotografii, co wpływa na artystyczne i estetyczne cechy zdjęć. Podsumowano podejścia do artystycznych i kompozytorskich rozwiązań projektowych współczesnej ukraińskiej fotoksiążki, podkreślono jej wyrazisty charakter narodowy, który budzi szczególne zainteresowanie na świecie.
\end{abstract}

Słowa kluczowe: fotoksiążka, projektowanie, foto-historia, foto-typologia, fotoksiążka. 


\title{
FEATURES OF THE AUTHOR'S UKRAINIAN PHOTOBOOK AS AN OBJECT OF ART DESIGN
}

\author{
Anna Safronova \\ Postgraduate Student at the Department of Ergonomics and Design \\ Kyiv National University of Technologies and Design (Kyiv, Ukraine) \\ ORCID ID: 0000-0003-4215-2646 \\ elrossa@ukr.net \\ Olena Safronova \\ Candidate of Technical Sciences, Associate Professor, \\ Head of the Department of Interior and Furniture Design \\ Kyiv National University of Technologies and Design (Kyiv, Ukraine) \\ ORCID: 0000-0002-3887-4825
}

\begin{abstract}
The paper considers a photo book as a form of art presentation, the purpose of which is the communication of the author with the viewer through the photographs, their symbolic content, composition and order. Based on the analysis of scientific sources, structural-morphological and subject analysis of modern foreign and Ukrainian photobooks, a classification of their types by the method of the content presentation has been developed; the most common reasons for combining photos into a series: a common theme; general idea; common plot; commonality of formal features; associations, were revealed. It was emphasized that the authorship of the most successful Ukrainian photo books, that were recognized at international and national exhibitions and competitions, belongs to the artists of the Kharkiv school of photography, that has influenced on the artistic and aesthetic features of the ukranian photographs. Approaches to artistic and compositional design solutions of a modern Ukrainian photo book was generalized, its expressive national character which is of special interest in the worl, was emphasized.

Key words: photo book, design, photo-history, photo-typology, self-publishing of photo books.
\end{abstract}

\section{ОСОБЛИВОСТІ УКРАЇНСЬКОЇ ФОТОКНИГИ ЯК ОБ'ЄКТУ АРТ ДИЗАЙНУ}

\author{
Анна Сафронова \\ аспірант кафедри ергономіки та дизайну \\ Київського національного університету технологій та дизайну (Київ, Украӥна) \\ ORCID ID: 0000-0003-4215-2646 \\ elrossa@ukr.net \\ Олена Сафронова \\ кандидат технічних наук, доцент, \\ завідувач кафедри дизайну інтер 'єру і меблів \\ Київського начіонального університету технологій та дизайну (Київ, Україна)
}

ORCID ID: 0000-0002-3887-4825

\begin{abstract}
Анотація. У роботі розглянуто фотокнигу як форму презентації мистецтва, метою якої є комунікація автора із глядачем через фотографії в ній, їх символічний зміст, композицію та порядок. На основі аналізу наукових джерел, структурно-морфологічного та предметного аналізу сучасних зарубіжних та українських фотокниг розроблено класифікацію їх типів за методом подання змісту; виявлено найбільш поширені підстави об'єднання фотографій у серію: загальна тема; загальна ідея; спільний сюжет; спільність формальних ознак, асоціацій. Акцентовано, що авторство найбільш успішних українських фотокниг, отримавших визнання на міжнародних і всеукраїнських виставках і конкурсах, належить митцям харківської школи фотографії, що впливає на художньо-естетичні особливості світлин. Узагальнено підходи до художньо-композиційних дизайн-рішень сучасної української фотокниги, підкреслено її виразний національний характер, що викликає особливий інтерес у світі.
\end{abstract}

Ключові слова: фотокнига, дизайн, фото-історія, фото-типологія, самовидання фотокниг.

Introduction. The development of information technology, digital photography and printing, software in the late XX and early XXI centuries, has opened to photographers and artists unique opportunities for creative projects in which photography can play the role of plastic material, the transformation and artistic processing of which is unlimited The photobook is one of such project, which is a kind of photo album with a unique design. The interest in this type of printing is evidenced by the large number of international festivals that take place annually in Europe, America and Japan (Art Book Fair Basel "I never read", C / O Berlin Bookdays, European Publishers Award for Photography, International Photobook Festival, Kassel, Germany, London Art Book Fair Atlanta Celebrates Photography - Photobook Fair and others). Since 2011, Time magazine has been publishing top lists of the world's best photobooks every year "The guardian", "New York times" constantly publish the articles about the photobooks. Since 2019, photobook festivals are taking place in Ukraine 
The photobook is characterized by exclusivity (small circulation); lack of market orientation (predominance of selfpublishing); increasing price over time (due to the artistic value of individual samples). In the practice of photography, the term «art object» is used in the author's photobook, which means an object of art or synthesis of arts, a valuable, non-utilitarian thing created from different materials and objects that convey the creative idea of the artist through visual interaction with the viewer and which is designed for the emotional reaction of man (Bazelyuk, 2019: 41).

Thus, the task of comprehensive research and theoretical understanding of the principles and approaches of creating a modern competitive photobook as an object of art design becomes relevant.

Main part. Photobook as a certain type of publications attracts much attention of researchers. Numerous publications consider photo albums, photobooks, photo editions in order to reveal their features, structure, content, creation technologies (Di Bello, 2011: 2). The artistic aspect of the photobook, the history of its formation and development to this day has been mainly covered by foreign authors, among whom the most famous are the works of photographer Martin Parr and critic Harry Badger. Their three-volume edition describes 200 Western European and Japanese photobooks from the moment of their appearance in the XIX century. Martin Parr describes the photobook as a unique kind of work of art, that aims to communicate with the viewer through the symbolic content, composition and order of photographs in it, and covers the last 172 years of world history developments of this object. Along with the photos, text and illustrative material (certain spots and groups of other graphic elements) can be included in the book as a collaboration or additional material too. The third volume "The Photobook: A History Volume III Hardcover" contains information about the formation of the idea of a photobook through photographs of various genres - from diaristic photographs of the area and street photography to the documentary photographs of historical events. This volume also analyzes the most famous publications of the second half of the twentieth century, highlights and best self-published works, although in general the work is quite descriptive.

Some aspects of presenting photographs of certain content are considered in the article by R. Mikhailova, dedicated to the American photographer Philip Halisman presented the semantic program of his photographs, which were collected in several photo albums, as thematically combined samples that illustrate his theory of "jampologos". Despite the fact that the article considers the work of only one photographer, it allows us to understand the ways of formation of a series of photographs, which is an important component of a photo album as a type of publication (Михайлова, 2018: 96).

The peculiarities of the photobook in relation to other types of art, such as cinema, music and literature, were noted in the dissertation research (The Photobook as a Reinvented Medium, 2017: 33). It is also important to define the role of the photobook as an informational environment that is influenced by the narrative. The third section of the dissertation focuses on the active development of self-publishing of photobooks, which is typical for the XXI century. A valuable experience in creating photographs for a photobook is reviewed and summarized in the works of well-known researchers in this field Bart (1964), Baker (2005) and Lockman (2013).

In Ukraine, despite the success of Ukrainian publications in international competitions, the modern photobook is not yet the subject of scientific research. The main source of information about it - is the publications posted on the Internet Online publications contain reviews of festival organizers and participants, interviews with famous photographers - Mykhailo Pedan, Dmytro Krakovych, Serhiy Kotchetov, members of the group "Shiloh" and others related to modern trends in the art of photography, successes and difficulties faced by Ukrainian artists, but do not have a scientific analysis. At the same time, the total number of publications devoted to this area is much smaller than those that consider the art of photography in general and its current trends. This state of affairs outlines the urgent need to study the photobook as a subject of artistic and design activities.

Formulation of the problem. Based on the review of literary sources, to analyse of the development of the art of photobooks in Ukraine and the world; to classify the types of photobook, depending on it's content; to identify the state and trends in the development of photobooks in Ukraine.

Method. The article uses visual-analytical analysis to process samples and written sources, typological - to identify criteria for the distribution of samples and their systematization, comparative - for stylistic, compositional, meaningful analysis of various works of photography, photo albums and other publications.

Research results and their discussion. The conducted researches allowed to generalize the features on which the modern competitive, demanded in the market photobook is created, originality and versatility of the concept, a way of transfer of idea of a photobook to the spectator; design, variety of approaches to shaping; typography technical skill, appropriate choice of materials and decor.

According to the way of presenting the content, photobooks can be divided into those that contain a certain photographic story, which means sequential disclosure of the topic in chronological order (photo-history) and those that contain a series of photos (photo-typology), combined thematically and associatively (photographs of objects of this type). One of the postmodern methods of conveying the author's idea to the audience is the so-called photoappropriation, which in structure can be both a photo-typology and a photo-history, depending on the author's idea and involves the use of "foreign" photos. In "pure form" the photographic materials used in the project may not have their own artistic value, but due to modification (for example, its involvement in a particular context), the photography used acquires a new meaning and becomes able to reveal the idea of the author. For example, artists from the Kharkiv School of Photography, the Odessa group "Shilo", and others applied to the photo-appropriation in order to rethink the past, change the point of view on familiar objects, and give them relevant content. Thus, for representatives of the Kharkiv school of photography, a common practice in creating photo projects is the use of archival photographs. Manipulating images that reflect the retrospective of the Soviet way of life, the authors deform it with the techniques of coloring and collage, or move it into an unusual context. Such techniques are involved 
in the photobook "In Search of My Father" by Natalia Reznik (2015), "Dnepropetrovsk School of Photography" by curators L. Goldstein and M. Khrushchak (2015).

The latest edition ("Total Photography") includes photo projects by the author of the Soviet era, which present coloring pages - tinted photographs that give the black and white photo the qualities of painting, as well as "retro" photographs of the author and his colleague Vladimir Shaposhnikov (fig. 1).

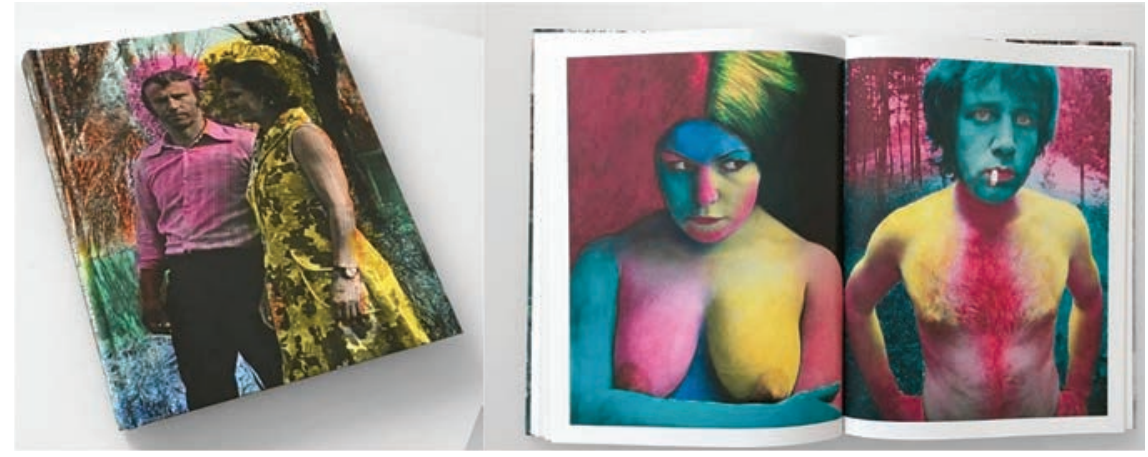

Fig. 1. Yevgeniy Pavlov, “Total Photography”, 2016

(source: https://rodovid.net/en/product/217/yevgeniy-pavlov-total-photography)

These techniques and methods do not contradict the statement of Andre Ruyet, a famous French analyst of the art of photography, that in the postmodern era photography, in addition to its establishment as an art form, preserved and developedits own aesthetic value and identity, has become a full-fledged material for other kinds of art. Note that the photo-typology as a form of presentation of the thematic photo project is associated with the works of the founders of the Dusseldorf School of Photography: August Sander, Karl Blossfeldt, Bernd and Hilla Becher, Bernd Becher's early works, in which he recreated industrial objects - gasholders, water towers, elevators, blast furnaces, marked by the emotional and analytical power of form and combined it in a series.They are now perceived as a "visual grammar" of a certain standard, when a set of individual images conveys the meaning of the project after perceiving all the photographs together. After all, the objects are free from aesthetic considerations. According to the author, they appeared as important works of architecture and engineering, which have their own unique style and reflect the era (Васильева, 2016: 32). Later, this technique was used by photographers for photo portraits, which were based on a problematic issue. A striking example is the photographs in the Portraits series (1981-1985) by Thomas Ruff, a representative of the same Düsseldorf school of photography who continued to work in the style of his teachers (Васильева, 2016: 33) The images of men and women from the former GDR make up a series of sixty portraits. Their photos, taken "like a passport", without emotions, facial expressions, gestures, that is, without being distracted from the essence, reveal something in common that unites them all. This is a kind of "attention task", designed to find nuances in seemingly similar photos. Thomas Ruff - an innovator who still overcomes the boundaries of traditional photography, learns new techniques, including "night vision", hand painting, stereoscopy, modernizes the subject - portrait, architectural, astrological and others.

To analyze the current state and trends in the development of art photography in Ukraine, the photobooks by Ukrainian photographers, which were noted at festivals in Europe and Ukraine and the works of young Ukrainian photographers, whose books received positive feedback from organizers and critics of this art in Ukraine were selected. In total, 30 photobooks published in 2000-2020 were analyzed.

The analysis showed that Ukrainian photobooks are characterized by an appeal to national issues and social problems; contradictory and tragic events that have occurred in Ukraine in recent decades.

The main issues that have arisen and remain relevant:

- social security of the person;

- the moral state of society;

- war.

Another significant feature of Ukrainian photobooks is a certain focus of photographers on their own experiences. The search for the author, his emotional state determines the selection of certain scenes, objects and phenomena, which he decides to capture with essentially documentary diligence. Most photobooks address issues or issues directly related to the author's area of residence (otherwise to another city where the author has spent a long period of time), and this area is usually limited to the city (not the country).

It is quite rare for Ukrainian photographers to choose objects for photography from other countries, despite the fact that many of them live and are publish their works abroad. The main ways of presenting the content of a Ukrainian photobook are photo-typology, less often - photo-history. The basis for combining photos in a series can include: a common theme; common idea; common plot; commonality of formal features; associative community. In the design of a Ukrainian photobook, there is often a minimalist interference in the compositional solution of the page in order to emhasize attention to the photo content. Often it is a photo on a page with a blank sheet next to it, or photo on a spread. In order to accentuate the photo, the intentionally reduction of one or more photos to a relatively large amount of white space on the cover is used. 
The modular grid is mostly as simple as possible. On the average in each photobook It is used from 2-3 variants of a modular grid.

Alexander Chekmenyov's photobook "Passport", which included photographs of 1994-1995 years, was created by a photographer in Luhansk on behalf of social services (fig. 2). Photos were made for certification of the elderly and sick people left physically unable to leave home, as well as those who could not receive photo services because the absence of money. Under such circumstances, O. Chekmenyov, was attracted by social workers, found himself in the homes of Luhansk homes, where he recorded the life of a stratum of people in the mid-1990s. The photobook "Passport" dedicated to them is a classical ecsmple of photo-typology with a minimalist graphic and polygraphic solution. Its concept is revealed by the introductory part, the color scheme of the cover, which corresponds to the national and ethnographic component, photos of the artist's own passport and a series of portraits of ordinary citizens of Ukraine, placed on translucent paper with a frame equal to a passport sheet. The main part of the book is portraits full of emotional tension, because despite of the requirements for a passport photo, Chekmenyov's photos included a photo of all the environment in which the person lived, where viewer could see the objects related to everyday life on the background. In the foreground it was the self-portrayed, social worker, their interaction. This technique has revealed the impressive details of the lives of many people.
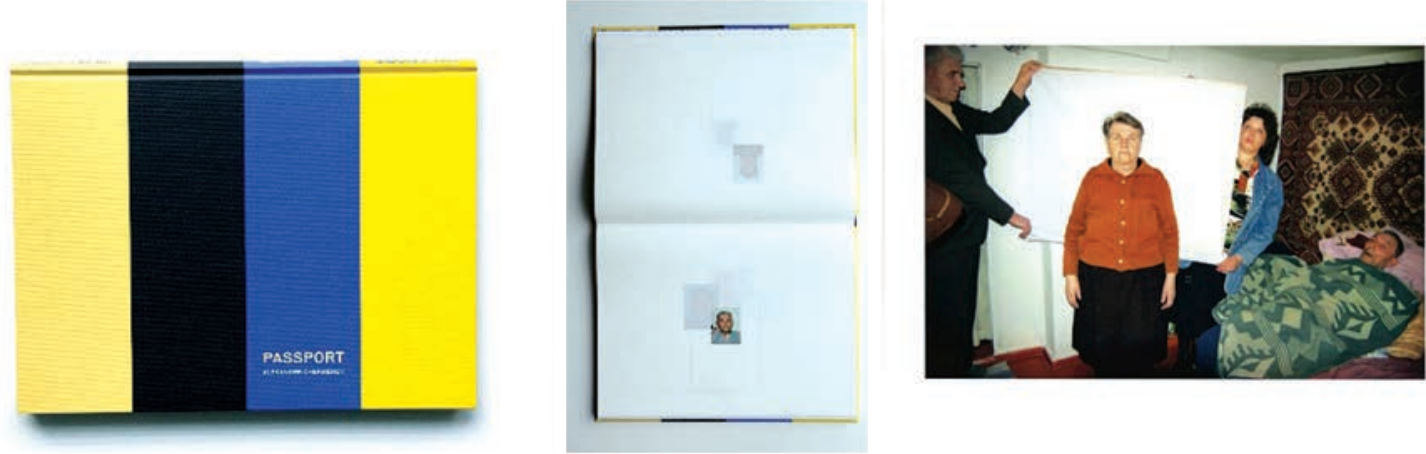

Fig. 2. Alexander Chekmenyov's, «Passport»

(source: https://collectordaily.com/alexander-chekmenev-passport/)

Thus, the main role in the compositional solution of O. Chekmenev's photobook belongs to the photographs: big sized with a minimum amount of explanatory text, small on a white background, etc. with a minimalist cover. Photographs are characterized by: clear reproduction without the effects of changing the depth of field (shooting on a wide-angle lens); color brightness that mimics film shooting; lack of artistic effects; achieving the impression of unprofessional shooting, naturalness, no posing by the subject, no visible retouching (post-processing of the frame). It is significant that such features are inherent in other Ukrainian photobooks that have received international recognition. These are "Kachalka. Muscle Beach" by Kirill Golovchenko (fig. 3), "Slavik Fashon" by Yurko Dyachyshyn (fig. 4), etc.

The original approach of creating photobook with use of a short script, which can not be called a photo story, is enshrined in the photobooks "Slavik Fashion", dedicated to the Lviv homeless. The author of Slavik's fix him in a different outfit on the streets of Lviv. The photos presented in the book, is a parody of of so-called lifestyle bloggers and fashion experts photos, who often publish their photos on the Internet, demonstrating their look and outfits. At the same time, the photobook raises the question of the fate of homeless people, reflecting a fairly typical representative of them. We see a destitute, sick person, an alcoholic, to whom no one cares, and the images he diligently reproduces, cause tears rather than a smile.

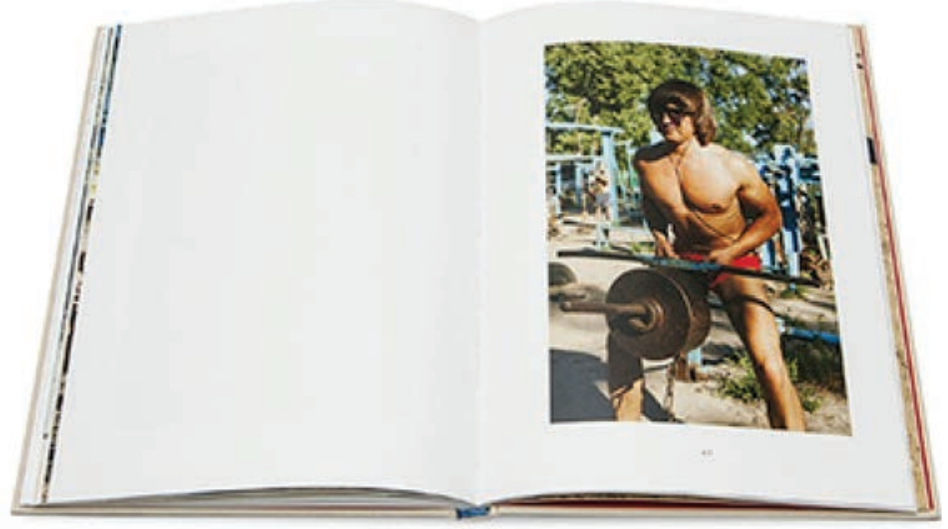

Fig. 3. Kirill Golovchenko, «Muscle Beach», 2012

(source: https://www.kirill-golovchenko.com/books) 

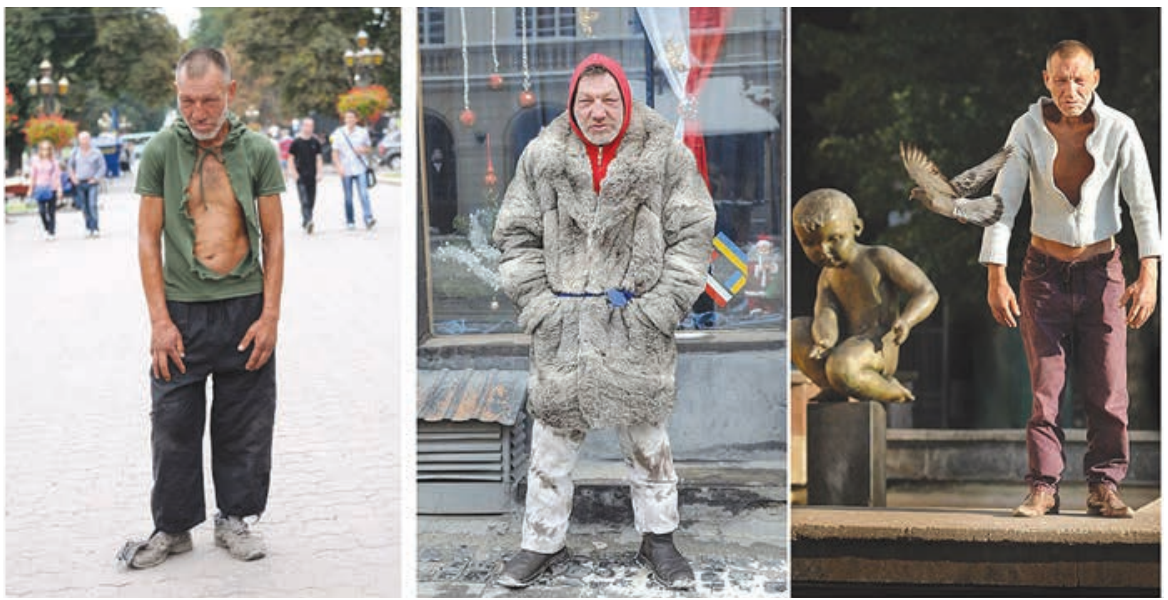

Fig. 4. Yurko Dyachishin, «Slavik Fashion», 2013

(source:https://bigpicture.ru/slavik-samyj-modnyj-bomzh-ukrainy/)

It is worth emphasizing that an important compositional component of a photobook is an explanatory text, usually concise, purely informative, that compile information about the subject, place and time of shooting. The purpose of the different variations of the text form in photobook: the disclosure of the essence of the photo, the transfer of the idea of the author of the subscription, the title; history, detailed description; visually active text: calligraphic, that have an independent artistic role in the assignments or to act as a supplement. However, the absence of a textual part in general is also possible, because the power of expressiveness for observing photographs and their compositional position, which, in turn. Thus, in V. Polyakov's photobook (fig. 5) the text is absent, in B. Mikhailov's "Diary" (fig. 6) there is a visually active text, which gives the impression of handwritten comments. In A. Bondar's photobook "Barricade", 2015 (fig. 7) the text is arranged in inlays. Transferred from the dictionary, the texts have an original look. In the photobook "Signatures of War" (fig. 8) the combinations of different text forms are used: manuscripts of Polaroid spells of veterans with text signatures to carry information about the person, images in photos.
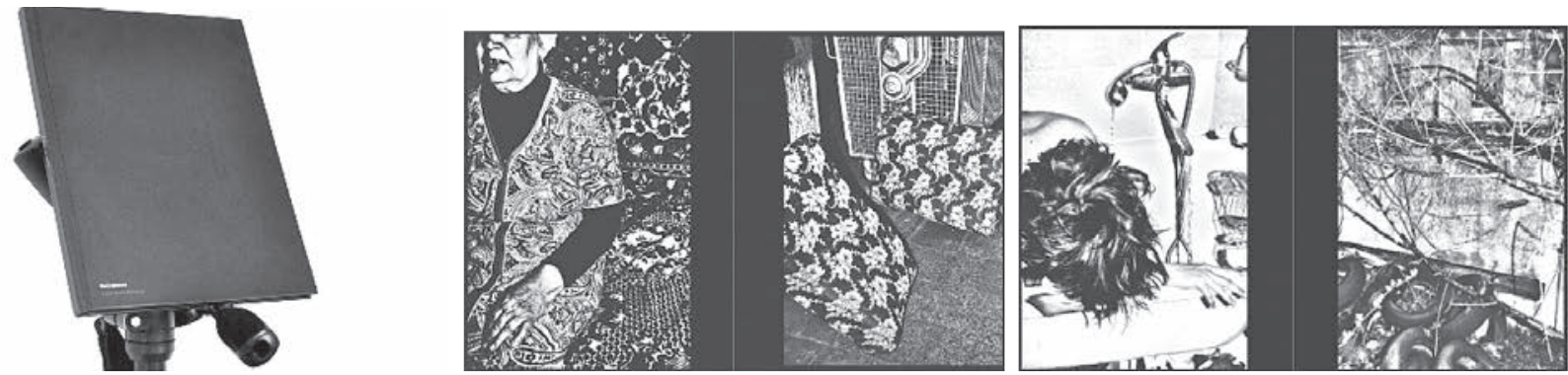

Fig. 5. Viacheslav Poliakov, "Backspaces", 2016

(source: https://via-poliakov.com/backspaces.html)
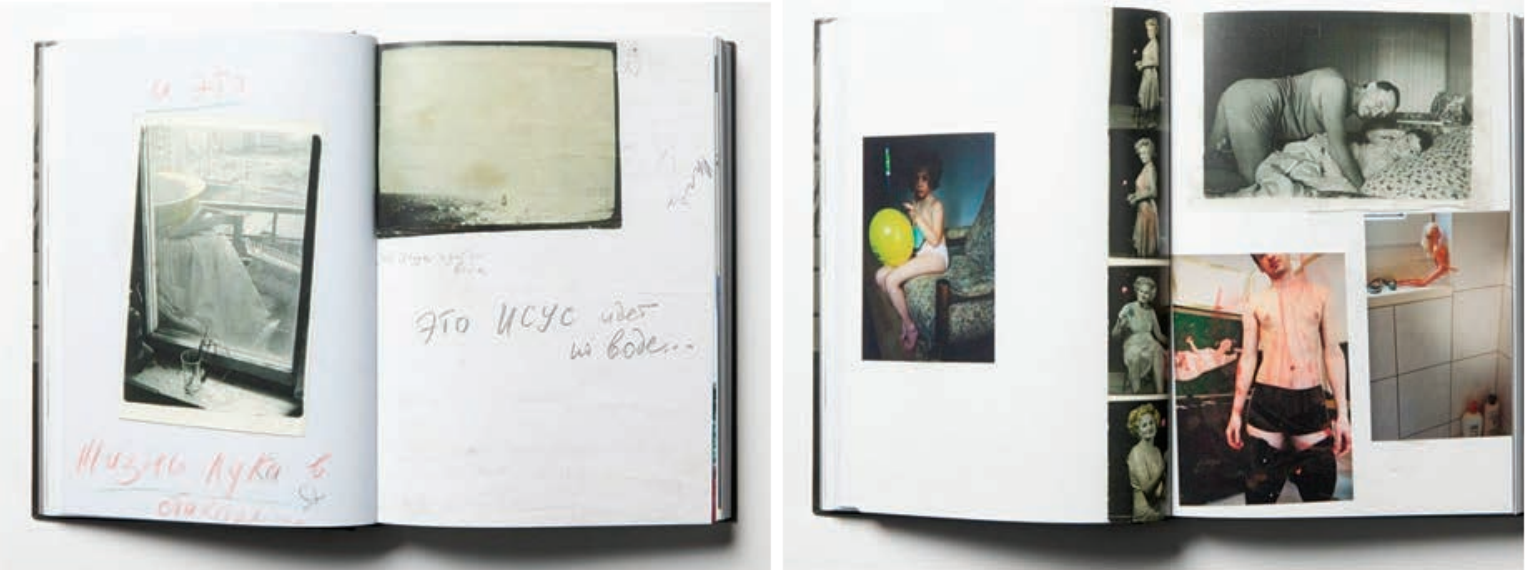

Fig. 6. Boris Mikhailov "Diary", 2015

(source: https://tipi-bookshop.be/shop/diary-by-boris-mikhailov) 

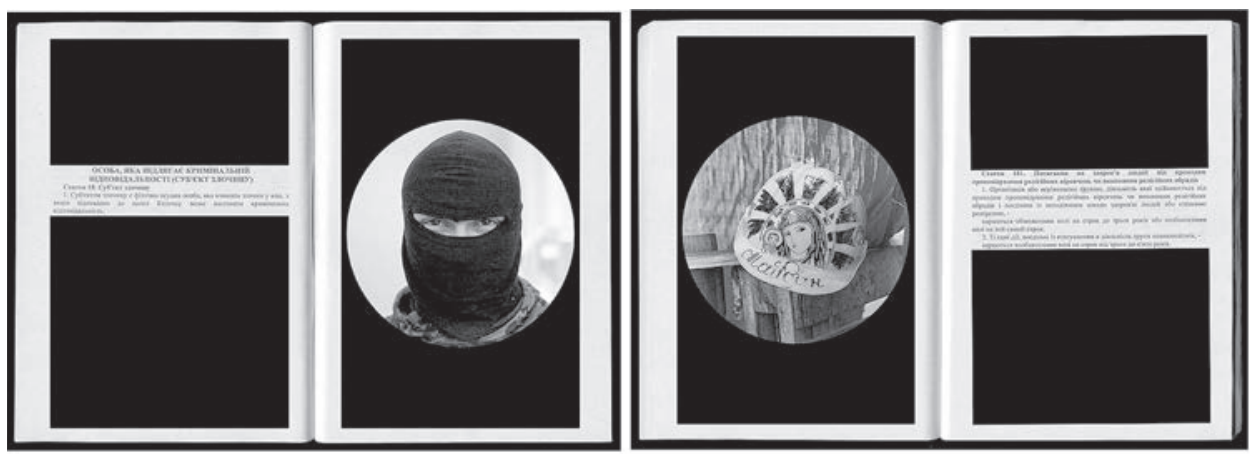

Fig. 7. Arthur Bondar "Barricade", 2015

(source: https://www.photographer.ru/cult/person/6635.htm)
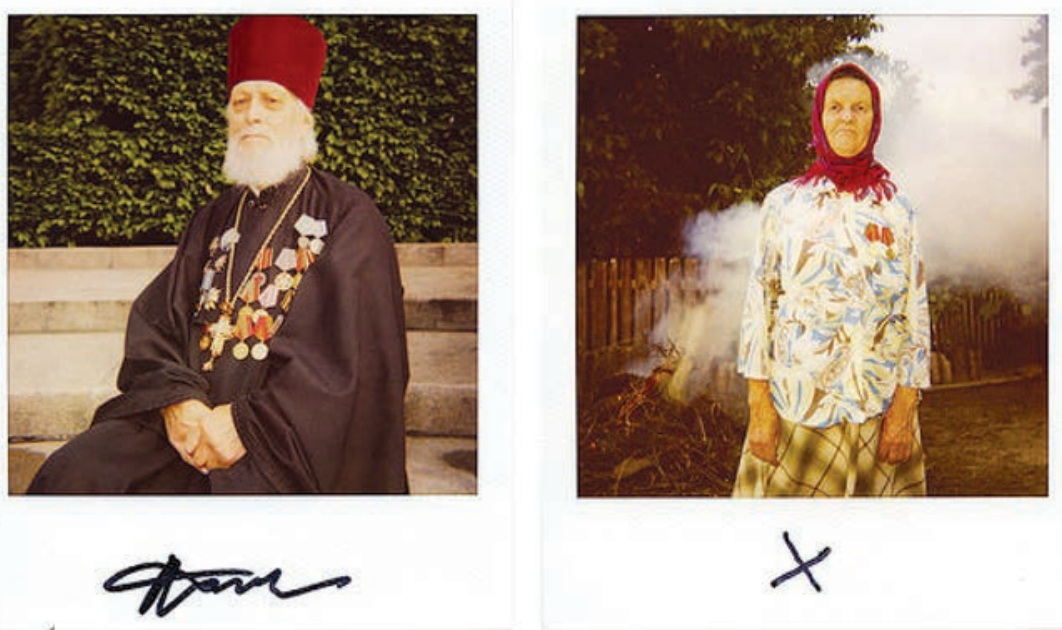

Fig. 8. Arthur Bondar "Signatures of War", 2015

(source: https://planeta.ru/campaigns/13510)

Conclusions. The photobook of the late XX-early XXI centuries has become a phenomenon of world photography, due to the fact that in the period of development and emergence of the new approaches to the problem of art synthesis, photography has shown itself as a material that can be used in any combination with other ways of figurative expression. In the field of modern communications, it has social, aesthetic and educational functions. Photobook is a printed visualization of the creative photographer's project and it can belong to the art objects by its properties. The main ways of presenting the content of a photobook, as well as the most common approaches of creating the concept of a photobook in Ukraine and the grounds for combining photos in a series are identified. It is emphasized that the characteristic feature of the modern Ukrainian photobook is its expressive national character, which is of special interest in the world. Approaches to compositional solutions and general stylistics of the Ukrainian modern photobook are generalized. The style of photos in the photobooks coincides with the trends and tendencies of the modern photography.

The study of European and world photobooks against the background of artistic events in Ukraine allows us to identify areas and prospects for its development, as well as current aspects of research

\section{Bibliography:}

1. Базелюк Н.Л. Форма як засіб створення художнього образу в арт-дизайні. Art and Design. 2019. № 3(07). C. 40. DOI: https://doi.org/10.30857/2617-0272.2019.3.4.

2. Васильева Е.В. Дюссельдорфская школа фотографии: социальное и мифологическое. Вестник СПбГУ. Сер. 15. 2016. № 3 C. 27-37 DOI: https://doi.org/10.21638/11701/spbu15.2016.302.

3. Di Bello P., Wilson, Shamoon Z. The Photobook: From Talbot to Ruscha and Beyond Paperback - 18 Dec. 2011.256 p.

4. Meiselman When Does an Artist's Appropriation Become Copyright Infringement? Dec 28, 2017. URL : https://www.artsy.net/article/artsy-editorial-artists-appropriation-theft (дата звернення 29.01.2021).

5. Михайлова Р. Художні прийоми в фотопортретах Філіпа Халсмана. Art and Design. 2018. № 1. С. $95-102$. DOI: https://doi.org/10.30857/2617-0272.2018.1.9.

6. The Photobook as a Reinvented Medium: Narrativity, Design and Publishing in the Twentieth and Twenty-First Century A dissertation submitted to the Dublin Institute of Technology in part fulfilment of therequirements for award of BA Photography by Alisha Doody. January 2017. DIT School of Media, College of Arts and Tourism. 52 p. 


\title{
References:
}

1. Bazelyuk, N. L. (2019) Forma yak zasIb stvorennya hudozhnogo obrazu v art-dizaynI. [Form as a means of creating artistic image in art design ] Art and Design. 3 (07). 40 - 47 DOI: https://doi.org/10.30857/2617-0272.2019.3.4 [in Ukrainian]

2. Vasileva, V. (2016) Dyusseldorfskaya shkola fotografii: sotsialnoe i mifologicheskoe. [Dusseldorf school of photography: social and mythological] Vestnik SPbGU - Bulletin of St. Petersburg State University. 3(15). 27-37. DOI: https://doi.org/10.21638/11701/spbu15.2016.302 [in Russian].

3. Di Bello, P., Wilson, C., Shamoon, Z. The Photobook: From Talbot to Ruscha and Beyond Paperback-18 Dec. 2011.256 p.

4. Meiselman, When Does an Artist's Appropriation Become Copyright Infringement? Dec 28, 2017. URL: https://www.artsy.net/article/artsy-editorial-artists-appropriation-theft (last accessed: 10.01.2020).

5. Mykhailova, (2018) Khudozhni pryiomy v fotoportretakh Filipa Khalsmana [Artistic techniques in photo-portraits of Philip Halisman]. Art and Design. №1. S. 95 - 102. DOI: https://doi.org/10.30857/2617-0272.2018.1.9 [in Ukrainian].

6. The Photobook as a Reinvented Medium: Narrativity, Design and Publishing in the Twentieth and Twenty-First Century A dissertation submitted to the Dublin Institute of Technology in part fulfilment of therequirements for award of BA Photography by Alisha Doody. January 2017. DIT School of Media, College of Arts and Tourism. 52 p.

DOI https://doi.org/10.51647/kelm.2020.5.4.12

\section{BALET A. CHACZATURIANA, "MASKARADA" W ODESKIM NARODOWYM TEATRZE OPERY I BALETU}

\author{
Harri Sevoian \\ Zastużony Artysta Ukrainy, \\ aspirant Katedry Reżyserii i Choreografii \\ Wydziału Kultury i Sztuki \\ Lwowskiego Uniwersytetu Narodowego im. Iwana Franki (Lwów, Ukraina), \\ kierownik zespolu baletowego \\ Odeskiego Narodowego Teatru Opery i Baletu (Odessa, Ukraina) \\ ORCID ID: 0000-0001-7836-2106 \\ sevoyan@ua.fm
}

Adnotacja. Artykuł analizuje historię tworzenia muzyki A. Chaczaturiana do dramatycznych spektakli, historię tworzenia Baletu E. Oganesiana „Maskarada”, strukturę baletu i jego tekstu muzycznego, los sceniczny na scenie Odeskiego Narodowego Teatru Opery i Baletu. Przeanalizowano prace kompozytorskie i kierownicze E. Oganesiana, odnotowano jego własne stylizowane fragmenty, korekty partyturowe tekstu muzycznego i cechy libretta. W artykule omówiono cechy scenicznego i choreograficznego wcielenia baletu w adaptacji baletmistrza H. Sevoiana i dyrygenta V. Kovalchuka, przyczyny jego aktualizacji i popularności, korelacje ze sztuką M. Lermontowa, cechy postaci. Pojawia się również kwestia komunikatywności współczesnego języka choreograficznego i roli nowoczesnych technologii w tworzeniu sympatii widzów ówczesnego dzieła akademickiego.

Słowa kluczowe: balet współczesny, choreografia klasyczna i nieklasyczna, secesja, komunikacja.

\section{A. KHACHATURIAN'S BALLET "MASQUERADE" IN THE ODESSA NATIONAL ACADEMIC OPERA AND BALLET THEATER}

\author{
Garri Sevoyan \\ Honored Artist of Ukraine, \\ Postgraduate Student at the Department of Directing and Choreography \\ of the Faculty of Culture and Arts \\ Ivan Franko National University of Lviv (Lviv, Ukraine), \\ Head of the Ballet Company \\ Odesa National Academic Opera and Ballet Theater (Odesa, Ukraine) \\ ORCID ID: 0000-0001-7836-2106 \\ sevoyan@ua.fm
} Abstract. The article examines the history of A. Khachaturian's creation of music for dramatic performances,
the history of E. Ogannisyan's creation of the ballet «Masquerade», the structure of ballet and its musical text, the stage
fate on the stage of the Odessa National Opera and Ballet Theater. The compositional and ldirecting work of E. Ogannisyan 